\title{
A Kantian Defense of Self-Ownership*
}

\author{
ROBERT S. TAYLOR \\ Political Science, Stanford University
}

\section{INTRODUCTION}

$\mathbf{T}$ HE name of Immanuel Kant has been repeatedly invoked in the contemporary debate over the concept of self-ownership. Robert Nozick, in Anarchy, State, and Utopia, argued that the rights of self-ownership "reflect the underlying Kantian principle that individuals are ends and not merely means; they may not be sacrificed or used for the achieving of other ends without their consent. Individuals are inviolable." ${ }^{1}$ G. A. Cohen, on the other hand, has strongly criticized Nozick's use of Kant and has suggested that Kantian moral principles, properly understood, may be inconsistent with self-ownership. ${ }^{2}$ Daniel Attas and George Brenkert have also taken Nozick to task, arguing that to treat ourselves as property is inconsistent with our duty to respect humanity in ourselves. ${ }^{3}$

Nozick's use of Kant in Anarchy, State, and Utopia is rather impressionistic: he makes only a few scattered references to Kant and the $2^{\text {nd }}$ (End-in-Itself) Formulation of the Categorical Imperative, and nowhere does he offer a full, detailed Kantian defense of either self-ownership or any other part of his theory. ${ }^{4}$ This observation, when considered in light of the strong and often persuasive criticisms that have been leveled against his position by Cohen and others, prompts the following question: is a Kantian defense of self-ownership even possible? This paper will attempt to show that such a defense is possible, not only by investigating Kant's views on self-ownership as found in two of his major works on ethics and political theory, the Groundwork of the Metaphysics of

"I am grateful to Chris Kutz, Shannon Stimson, Eric Schickler, Carla Yumatle, James Harney, Sharon Stanley, Robert Adcock, Jimmy Klausen, and three anonymous referees for their helpful comments and suggestions.

${ }^{1}$ Robert Nozick, Anarchy, State, and Utopia (New York: Basic, 1974), pp. 30-1; also see pp. 32, 228.

${ }^{2}$ G. A. Cohen, Self-Ownership, Freedom, and Equality (Cambridge: Cambridge University Press, 1997), pp. 238-42; also see pp. 211-13.

${ }^{3}$ Daniel Attas, "Freedom and self-ownership," Social Theory and Practice, 26 (2000), 1-23 at pp. 11-15; George Brenkert, "Self-ownership, freedom, and autonomy," Journal of Ethics, 2 (1998), 27-55 at pp. 50-2.

${ }^{4}$ The contrast with John Rawls, whose Kantianism is spelled out in exquisite detail in $\$ 40$ of A Theory of Justice (Cambridge, MA: Harvard University Press, 1999), is instructive.

(C) Blackwell Publishing, 2004, 9600 Garsington Road, Oxford OX4 2DQ, UK and 350 Main Street, Malden, MA 02148, USA. 
Morals and the Metaphysics of Morals, ${ }^{5}$ but also by offering two novel Kantian defenses of self-ownership that are based primarily on the $1^{\text {st }}$ (Universal Law) and $3^{\text {rd }}$ (Autonomy) Formulations of the Categorical Imperative, respectively.

\section{KANT ON SELF-OWNERSHIP}

One of the first obstacles to a Kantian defense of self-ownership is Kant's own seeming rejection of the concept. In MM, Kant asserts that "someone can be his own master but cannot be the owner of himself (cannot dispose of himself as he pleases)—still less can he dispose of others as he pleases-since he is accountable to the humanity in his own person." ${ }^{6}$ The reason for Kant's rejection of selfownership, so construed, is not difficult to discern: if self-ownership implies a liberty to "dispose of oneself as one pleases," then it is inconsistent with the $2^{\text {nd }}$ Formulation of the Categorical Imperative, which imposes a duty on all rational beings to "so act that you use humanity, whether in your own person or in the person of any other, always at the same time as an end, never merely as a means." 7 Throughout his writings, Kant maintains that any number of consensual or even self-regarding acts are inconsistent with respect for humanityin-oneself, including suicide, voluntary servitude, organ sales and self-mutilation, prostitution, premarital sex, and even the failure to develop one's talents. ${ }^{8}$ Selfownership apparently licenses such acts, which is why Kant rejects it.

His rejection of self-ownership may seem surprising in light of his frequent defenses of bodily integrity and independence. Kant strongly condemned "assaults on the freedom and property of others," and he declared freedom to be the "one innate right," an aspect of which is "a human being's quality of being his own master." ${ }^{9}$ The notion of "being one's own master," especially when combined with the emphasis on noninterference with the freedom of others, seems tantalizingly close to the concept of self-ownership, yet Kant's objections to it retain their force.

In order for a Kantian defense of self-ownership even to remain a possibility, there must be some way to reconcile Kant to it, in spite of textual evidence to the contrary. The key to such a reconciliation is Kant's use of the phrase "dispose of oneself as one pleases." To use Hohfeldian terminology, Kant is claiming that owning oneself implies a liberty to "dispose of oneself as one pleases," that is, an absence of self-regarding duties. Strictly speaking, however, self-ownership

${ }^{5}$ Hereafter GMM and MM, respectively. Immanuel Kant, Groundwork of the Metaphysics of Morals, trans. Mary Gregor (Cambridge: Cambridge University Press, [1785] 1997); Immanuel Kant, Metaphysics of Morals, trans. Mary Gregor (Cambridge: Cambridge University Press, [1797] 1996).

${ }^{6} M M$, p. 56.

${ }^{7}$ GMM, p. 38; emphasis added.

${ }^{8}$ Suicide: ibid.; voluntary servitude: $M M$, pp. 66,104 ; organ sales and self-mutilation: $M M$, p. 177; prostitution: $M M$, p. 63; premarital sex: $M M$, p. 127; failure to develop one's talents: GMM, pp. 38-9.

${ }^{9}$ Ibid., p. 38; $M M$, p. 30. 
implies no such thing. As I will show in the next section, the incidents (claimrights) that constitute self-ownership impose perfect duties of physical noninterference upon others-that is all. Such rights are completely consistent with self-regarding (albeit unenforceable) duties the self-owner may be under, such as a duty to respect humanity-in-oneself. More generally, a right does not imply a corresponding liberty, or absence of duties, regarding the protected action. ${ }^{10}$ For example, there is nothing contradictory about the following pair of claims:

I have a right to commit suicide (that is, you have a perfect duty not to interfere), but I am not at liberty to do so (that is, I have a perfect though unenforceable self-regarding duty to continue living).

In fact, both of these duties- the duty not to interfere and the duty to continue living-might conceivably be direct implications of the more general CI-duty to respect humanity "in your own person or in the person of any other."

If the logic of the preceding is correct, then the way has been cleared for a Kantian defense of self-ownership. Self-regarding duties we may have (such as duties to preserve our lives and freedom and to develop our talents) are not inconsistent with self-ownership, properly understood. The libertine notion of "disposing of oneself as one pleases" is unrelated to the central concern of selfownership, which is preventing the physical coercion of some persons by others.

\section{FROM A DUTY OF NONINTERFERENCE TO SELF-OWNERSHIP}

The Kantian defenses of self-ownership in the following sections argue in favor of a duty of physical noninterference, that is, a duty to respect the bodily integrity of other people. This duty is a perfect duty, meaning that it specifies not only who must discharge it but also to whom it is owed. Moreover, it is a universal perfect duty: all rational beings owe it to all other rational beings. ${ }^{12}$ This focus on duty is necessitated by the very nature of the Kantian project, which defines moral actions as those that are consistent with, and motivated by, universal maxims of just conduct. ${ }^{13}$

In what sense, however, can an argument for the duty of physical noninterference be an argument for self-ownership? First, consider that all perfect duties have correlative rights. As Onora O'Neill writes, "because perfect obligations require action for all or for specified others, they have correlative definite, assigned rights, which can be claimed or waived and are in principle

\footnotetext{
${ }^{10}$ For an extended defense of this proposition, see Jeremy Waldron, "A right to do wrong," Liberal Rights (Cambridge: Cambridge University Press, 1993), pp. 63-87.

${ }^{11} \mathrm{I}$ am not claiming that Kant himself held this view. He states in $M M$ that "killing oneself is a crime (murder)" (p. 176). Thus, he would have been as unlikely to endorse a duty of noninterference in suicide as a duty of noninterference in homicide.

${ }^{12}$ Onora O'Neill, Constructions of Reason: Explorations of Kant's Practical Philosophy (Cambridge: Cambridge University Press, 1989), p. 189.

${ }^{13} G M M$, p. 31.
} 
enforceable." ${ }^{14}$ Because the duty of noninterference is a perfect duty, it has a correlative right, which is the right of exclusion, that is, the right to forbid trespass on one's own person.

Second, consider that certain other rights can be derived from this right of exclusion. For example, the right of use, if it is understood as a temporary right of exclusion conditional upon use (as when one claims territory in a public park by throwing down a picnic blanket), can be directly derived from the right of exclusion: a permanent right of exclusion trivially includes a temporary right of exclusion. A more important example is the right of transfer, which can be indirectly derived from the right of exclusion. If I want to transfer an item to another person, for instance, I can desist from using the item myself, cease exercising my right of exclusion against that person, but continue exercising it against third parties (unless the transferee specifies otherwise). Moreover, I can bind myself to do these things by making an enforceable promise to the transferee, a power that autonomous agents are traditionally held to possess. (For a fuller discussion of self-legislation, see Section V.) This indirect derivation of an (effective) right of transfer from the right of exclusion may present special problems when the item in question is a person (for example, the limitations to my use of my own body after its transfer would have to be spelled out carefully, as in certain labor contracts), but they are not in principle insoluble.

Finally, consider that the rights just described-the rights of use, exclusion, and transfer over one's own person-constitute one conception (though not the only one) of self-ownership. John Christman, for example, defines the term in precisely this way. ${ }^{15}$ This conception of self-ownership does not include the right to labor income, distinguishing it from Nozick's. ${ }^{16}$ It does, however, possess the apparently irreducible minimum of rights necessary for a conception of selfownership and can thus serve as a component for other, more extensive conceptions.

The somewhat surprising conclusion of this multistage analysis is that when we argue for a duty of noninterference with other persons, we are in effect arguing for a particular conception of self-ownership. If this conclusion is true, then a Kantian defense of self-ownership (so construed) can simply focus on establishing a universal, perfect duty of physical noninterference with others. I will use precisely this strategy over the next two sections.

\section{THE UNIVERSAL LAW ARGUMENT FOR SELF-OWNERSHIP}

According to Kant's $1^{\text {st }}$ Formulation of the Categorical Imperative, one should "act only in accordance with that maxim through which you can at the same

${ }^{14}$ O’Neill, p. 191. Also see Chapter 5 of John Stuart Mill's essay Utilitarianism.

${ }^{15}$ John Christman, The Myth of Property: Toward an Egalitarian Theory of Ownership (Oxford: Oxford University Press, 1994), p. 160.

${ }^{16}$ Nozick, Anarchy, State, and Utopia, p. 172. 
time will that it become universal law." 17 Thus, one of the most straightforward ways to construct a Kantian defense of self-ownership is to show that maxims counseling physical coercion against other people cannot be universalized and are therefore illegitimate. A failure in universalization will occur if the universalized maxim cannot be conceived without contradiction ("contradiction in conception") or if it cannot be willed without contradiction ("contradiction in will"). Kant associates the first kind of contradiction with "strict or narrower (unremitting) duty," such as physical noninterference with others or truth telling, and the second kind with "wide (meritorious) duty," such as beneficence or the development of one's talents. ${ }^{18}$ In this section I will therefore devise two distinct but related versions of the physical-coercion maxim-the Exploitation and Paternalism Maxims, respectively_and show that neither can be successfully universalized because the universalization of each involves a contradiction in conception.

\section{A. Exploitation Maxim (Treat Rational Agents as Animals):}

"I will physically coerce other people if such coercion is necessary to advance my interests."

Can we conceive of a world in which such a maxim were a universal law? In trying to answer this question, we should look for guidance to Kant's most powerful example of a maxim whose universalization involves a contradiction in conception: the maxim that "when I believe myself to be in need of money I shall borrow money and promise to repay it, even though I know that this will never happen." ${ }^{19}$ Universalizing this maxim of deception (that is, generalizing it and making it a law of nature ${ }^{20}$ ) undermines the very condition (trust) that would make the maxim effective-as Kant says, if this maxim were universalized "no one would believe what was promised him but would laugh at all such expressions as vain pretenses." ${ }^{21}$ We therefore cannot even conceive of a world governed by such a maxim.

If we attempt to universalize the Exploitation Maxim, a similar problem arises. Just as a universalized maxim of deception undermines the very condition (trust) that makes deception effective, so a universalized maxim of coercion

${ }^{17} G M M$, p. 31.

${ }^{18}$ Ibid., p. 33.

${ }^{19}$ Ibid., p. 32.

${ }^{20}$ John Rawls identifies a procedure-which he refers to as the Four-Step CI-Procedure-for universalizing a maxim: first, state the maxim; second, generalize the maxim; third, transform the generalized maxim into a law of nature; finally, append this law of nature to existing laws of nature and analyze the resulting "social equilibrium"; "Themes in Kant's Moral Philosophy," Collected Papers, ed. Samuel Freeman (Cambridge, MA: Harvard University Press, 1999), pp. 497-528, especially pp. $498-506$.

${ }^{21}$ GMM, p. 32. 
undermines the very condition (passivity ${ }^{22}$ ) that makes coercion effective. Effective coercion requires that the coercer himself be uncoerced: he must be free to act upon other people as an artist acts upon his medium or as a trainer acts upon his animal. If others responded to him in kind, he would find his own attempts at coercion stymied. Thus, when we will a maxim of coercion, we are in effect willing that the opposite of our maxim (passivity) become a universal law-but we make an exception to this law for ourselves, thereby illegitimately privileging our own interests. ${ }^{23}$

\section{B. Paternalism Maxim (Treat Rational Agents as Children):}

"I will physically coerce other people if such coercion is necessary to advance their interests.”

Again, can we conceive of a world in which such a maxim were a universal law? The primary danger of such a maxim is that it can undermine the conditions of effective agency when acted on. In order to be an autonomous agent, one must be capable of self-control, because the human will is naturally untoward-if it were not, men would be gods or angels, and law, will, and action would always form a seamless whole. ${ }^{24}$ The capacity for self-control must be developed largely through its exercise, but those who act on the Paternalism Maxim create an environment where self-control is superfluous: they substitute their wills for the recalcitrant wills of those whom they aid. The self-control of their beneficiaries will therefore atrophy from disuse. Kant himself makes this argument on at least two occasions:

Virtue cannot be tanght merely by concepts of duty or by exhortations (by paraenesis), but must instead be exercised and cultivated by efforts to combat the inner enemy within man (asceticism).

We cannot ripen to [freedom] if we are not already established in it... [and] we do not ripen to freedom otherwise than through our own attempts. ${ }^{25}$

Thus, those who act on the Paternalism Maxim subvert the agency of their beneficiaries-not directly, but indirectly, by diminishing their capacity for selfcontrol, which is a precondition for effective agency and autonomous willing. The subversion is more subtle here than in the case of exploitation but no less real.

\footnotetext{
22 "Passivity" is used here in the following very specific sense: "submission ... to external force or another's will” (OED).

${ }^{23}$ GMM, p. 34. Also see Barbara Herman, The Practice of Moral Judgment (Cambridge, MA: Harvard University Press, 1993), p. 126, and Christine Korsgaard, Creating the Kingdom of Ends (Cambridge: Cambridge University Press, 1996), pp. 133-59.

${ }^{24}$ See GMM, p. 46, on the "holy will."

${ }^{25}$ MM, p. 221; Immanuel Kant, Religion Within the Boundaries of Mere Reason and Other Writings, ed. Allan Wood and George di Giovanni (Cambridge: Cambridge University Press, [1793] 1998), p. 180n. Also see Kant's sharp criticisms of paternalism in both MM, p. 94 and "Theory and practice," Political Writings, ed. Hans Reiss (Cambridge: Cambridge University Press, 1991), p. 74.
} 
We are now in a position to see why a universalized Paternalism Maxim involves a contradiction in conception. By the argument of the preceding paragraph, a universalized maxim of paternalism would diminish each agent's capacity for self-control. But self-control is a necessary condition for the effective willing of any action, including paternalistic action. Laziness, indifference, or any number of other inclinations might lead us to renege on our obligation to intervene paternalistically in the lives of others. Self-control would help us to overcome these inclinations and discharge our duty, but by willing a universalized maxim of paternalism, we deprive ourselves of this very capacity. Therefore, we cannot even conceive of a world in which such a maxim were a law of nature. ${ }^{26}$

\section{THE AUTONOMY ARGUMENT FOR SELF-OWNERSHIP}

The argument of the last section was Kantian in a decidedly traditional sense: maxims were proposed, universalized, and then subjected to a contradiction in conception test. The argument in this section is less orthodox, but will hopefully tease out some elements of the Kantian approach that have not previously been emphasized. Specifically, this section will invert the usual progression of moral argument: it will start with current moral practice, move to the moral intuitions that appear to motivate this practice, and end with an attempt to find principles that will justify these intuitions. Such an "inductive" approach may seem out of place in a paper exploring potential Kantian defenses of self-ownership-after all, Kant strenuously argued that "empirical principles are not at all fit to be the ground of moral laws." ${ }^{27}$ But the argument of this section is "inductive" only in style of presentation, not in substance. To anticipate its conclusion: the $3^{\text {rd }}$ (Autonomy) Formulation of the Categorical Imperative implies a status hierarchy of the world's agents and a parallel system of differential treatment, including the proscription of physical coercion against competent adults (as required for self-ownership).

Given the indirect nature of this section's argument, I will outline it here. The argument will be developed in three stages:

1. Moral Practice: How do we treat people as ends-in-themselves? In this subsection, I will begin the process of elucidating our moral practice with an example and by thinking about our treatment of nonrational agents. I will end by proposing a hierarchy of agents, a hierarchy that describes in a compact fashion how we think about ourselves vis-à-vis other agents.

2. Moral Intuition: Why do we treat people as ends-in-themselves? In this subsection, I will show that our notions of how we should treat others is

\footnotetext{
${ }^{26}$ Thomas Hill makes a complementary case against submission to exploitation and paternalism in "Servility and self-respect," Monist, 57 (1973), 87-104.

${ }^{27}$ GMM, p. 48 .
} 
intimately connected with the idea of status-more specifically, we tend to regard as a status wrong the treatment of rational agents as nonrational agents.

3. Moral Principle: How might this attitude be justified? In this subsection, I will attempt to justify the idea of status using Kant's notion of man as a selflegislating being. By so doing, I will provide an intellectual foundation for the differential treatment of agents and, by implication, for our current moral practice.

\section{A. Moral Practice}

According to Kant's $2^{\text {nd }}$ Formulation of the Categorical Imperative, one should "so act that you use humanity, whether in your own person or in the person of any other, always at the same time as an end, never merely as a means." ${ }^{28}$ How does one go about giving substance to the idea of treating another rational agent "as an end, never merely as a means"? Clearly, some uses of rational agents as means are considered acceptable-for example, fair, voluntary economic exchanges. ${ }^{29}$ The real question is: what uses of rational agents as means fail to treat them as ends-in-themselves? Consider the following example: agent $A$ wants to use agent $B$ to achieve end $X$. Straightforward instrumental rationality dictates that $A$ use the least-cost method to secure $B$ 's cooperation in the achievement of $X$. This approach would seem to require $A$ to use an "escalating" strategy to obtain $B$ 's assistance, a strategy that might look something like this:

1. Enlisting $B$ as a partner (determining whether he shares $A$ 's interest in $X$ );

2. Enlisting $B$ as a volunteer (playing upon his sympathy, perhaps);

3. Hiring $B$ as an employee, honestly (speaking to his economic interest);

4. Hiring $B$ as an employee, fraudulently (hiding certain conditions of employment);

5. Coercing B, indirect (threatening physical force against him);

6. Coercing $B$, direct (using physical force against him).

$A$ would progress through the actions on the list, starting with action one (presumably the least costly), until he procured B's assistance.

Before thinking about whether any of these actions fail to respect $B$ as an end, we should think instead about replacing $B$ with some nonrational agent (that is, an agent who is incapable of recognizing, obeying, and acting from the moral law). Consider the following two types of nonrational agents: children and animals. ${ }^{30,31}$ Very roughly speaking, parents are allowed to use actions one

\footnotetext{
${ }^{28}$ Ibid., p. 38.

${ }^{29}$ See Thomas Hill, Dignity and Practical Reason in Kant's Moral Theory (Ithaca, NY: Cornell University Press, 1992), p. 45.

${ }^{30}$ In some cases, children may be as capable as adults of recognizing and obeying the moral law. More than adults, however, their actions, even when consistent with the moral law, are the result of
} 
through three to secure cooperation from children for a wide variety of ends. Actions four through six, on the other hand, are generally disallowed unless the end in question serves the child's "best interests," especially the cultivation of his or her nascent rationality. For example, nobody would question the actions of parents who used force to prevent their child from walking into traffic or skipping school, but many would question the actions of parents who used force of equal severity to get their child to play checkers with them. Thus, force and fraud may be allowable under some conditions, but only for "paternalistic" reasons. Like agent $A$, parents will no doubt want to employ an "escalating" strategy for achieving their ends-persuasion will be better than trickery, which will (in some circumstances) be better than force.

With regard to animals, actions one through three are usually infeasible, for obvious reasons. Humans are generally allowed to use any combination of actions four through six (dangling a carrot in front of a mule, beating it with a stick, etc.) to achieve their ends, within rather broad bounds. Cruelty is sometimes prohibited, and the property rights of others in their animals must be respected, but otherwise people are free to use animals as they please. As with children, an "escalating" strategy will usually be dictated by instrumental rationality (for example, carrots should be used before sticks).

Given what has been said, I can create a tentative hierarchy of agents, a hierarchy that describes in a compact fashion how we think about ourselves visà-vis other agents.:

1. Rational agents (allowable actions: 1-3 [see below]);

2. Children (allowable actions: 1-3 [usually], 4-6 [if paternalistic]);

3. Animals (allowable actions: 4-6 [others infeasible]).

The first category and its associated allowable actions (yet to be justified) will turn out to be the most important for a Kantian defense of self-ownership: they indicate inter alia that physical coercion is not to be used against rational agents, that is, that bodily integrity and the right of exclusion are to be respected.

\section{B. Moral InTUITION}

Now to explain the purpose of this hierarchy. Thomas Nagel uses the concept of "inviolability" to clarify the nature of deontological constraints, of which the

a heteronomous will, i.e., a will guided by "attraction or constraint" (GMM, p. 41). As they mature, they will (hopefully) internalize the moral law and come to see it not as something imposed from without, but rather as a code given to oneself, a product of self-legislation. I will later return to this point.

${ }^{31}$ This categorization of nonrational agents is not intended to be exhaustive. For example, mentally incompetent adults constitute a separate category of nonrational agents. They cannot be categorized as children because they are permanently nonrational. Could they be categorized as animals? They are, after all, animate, sensitive, and permanently nonrational. The human conscience revolts against such a possibility, but it seems difficult to argue against, at least on Kantian grounds. Such difficulties provide one motivation for feminist criticisms of Kantian moral and political theories, e.g., Susan Okin, Justice, Gender, and the Family (New York: Basic, 1989). 
directive "so act that you use humanity ... as an end, never merely as a means" is a very general example. Nagel explicitly links the inviolability of persons to the concept of "status" when he says that "to be inviolable does not mean that one will not be violated. It is a moral status: It means that one may not be violated in certain ways-such treatment is inadmissible, and if it occurs, the person has been wronged...." 32 The word "status" has several related definitions. One definition is "the legal character or condition of a person or thing" (American Heritage Dictionary). Another, closely related meaning is "a relative position in a ranked group" (ibid.). But as we shall see, the status of human beings in the first sense (specifically, as inviolable ends-in-themselves) is inextricably connected to their status in the second sense (as agents located in a hierarchy). This observation will help us identify actions that fail to treat rational agents as ends.

We are now in a position to return to my original question about which of the six actions listed earlier fail to respect $B$ as an end. Actions 1 through 3 are generally thought to treat rational agents as ends (as well as means), because they elicit voluntary cooperation in a manner that is open and forthright. Agent $A$ treats agent $B$ as an equal when he takes actions 1 through 3 because he seeks $B$ 's informed consent, thereby respecting $B$ 's status as an autonomous, rational agent with ends of his own. One might point out that children are often treated in the same way, which is quite true, and to that extent they are being treated as rational agents. In fact, allowing actions 1 through 3 to be taken towards children is one way to cultivate their nascent rational agency. Still, there are limits involved where children are concerned: recruiting a child for extracurricular athletic activities is usually looked at very differently than recruiting a child for full-time work in lieu of an education. This difference is explained by the inchoate nature of the child's rational faculties, especially his or her foresight. ${ }^{33}$

What about actions 4 through 6? If agent $A$ takes these actions for paternalistic reasons, he is treating agent $B$ as a child. The kindly bartender who secretly waters down an inebriated patron's drinks, the parents who threaten to "rescue" their adult children from cults, and the bystanders who forcibly prevent a suicide can all be seen as infantilizing the recipients of their help. Such actions often generate an anger on the part of the recipient that seems completely out of proportion to whatever wrong is done: after all, there are plenty of other bars, cults, and bridges to which to turn. But this anger results not from the size of the injury, but rather from the perceived lack of respect for status that the action indicates. ${ }^{34}$ To use force and fraud for paternalistic reasons is in effect to push the recipient down the agent hierarchy, to treat him as an unequal.

\footnotetext{
${ }^{32}$ Thomas Nagel, "Personal rights and public space," Philosophy \& Public Affairs, 24 (1995), 83-107 at pp. 89-90 (my emphasis). Also see Frances Kamm, "Nonconsequentialism, the person as an end-in-itself and the significance of status," Philosophy \& Public Affairs, 21 (1992), 354-89.

${ }^{33}$ For a discussion of children's moral status that is informed by Kant's practical philosophy, see Tamar Schapiro, "What is a Child?" Ethics, 109 (1999), 715-38.

${ }^{34}$ Nagel, "Personal rights and public space," p. 95.
} 
If agent $A$ takes these actions for nonpaternalistic reasons, the affront to rational agency is much worse: he is treating agent $B$ as an animal. The usedcar dealer who uses deception to sell his lemon is treating his customer no differently than the farmer treats his mule when he dangles a carrot before it. Antebellum plantation overseers may have used the same whip for both their slaves and cattle. Such actions push their victims even further down the agent hierarchy, out of our species altogether. They constitute a profound status wrong, a relegation of fellow rational agents to the realm of unequals.

\section{Moral Principle}

The moral intuitions just expressed are quite strong: there does appear to be a tight connection between the status of an agent (that is, his place in the agent hierarchy) and the actions that may legitimately be taken towards him. But the argument cannot end here. We must now try to discover a moral principle that will not only justify the connection between status and action but also explain the normative significance of status itself. This latter task is especially important, given the history of the concept of "status," which has been used to defend highly inegalitarian social systems. (The inferior status of women, slaves, etc., was no doubt quite "morally intuitive" to those who benefited from their oppression.) As I shall now argue, the idea of man as a self-legislating being, which is central to Kant's work, can provide the missing moral foundation for hierarchy and can justify the link between status and action.

Kant seems to fix on reason as being the distinguishing feature of fully developed human beings and the justification for their differential treatment. By reason, however, he does not mean merely the ability to connect cause and effect, do arithmetic, etc., of which children might well be capable. He is instead concerned with the ability to act from a moral law given to oneself, that is, with the capacity for self-legislation. This feature marks out the rational agent as something different from an animal (which is unable to follow any law) or a child (who may act in conformity with the law, out of a fear of punishment or a hope of reward, but not yet from the law as a self-chosen regulative principle).

In a very dense passage of GMM, Kant connects the three formulations of the Categorical Imperative and, in the course of doing so, introduces the idea of self-legislation:

The ground of all practical lawgiving lies (in accordance with the $\left[1^{\text {st }}\right.$ Formulation]) objectively in the rule and the form of universality which makes it fit to be a law (possibly a law of nature); subjectively, however, it lies in the end; but the subject of all ends is every rational being as an end in itself (in accordance with the $\left[2^{\text {nd }}\right.$ Formulation]); for this there follows now the [ $3^{\text {rd }}$ Formulation], as the supreme condition of its harmony with universal practical reason, the idea of the will of every rational being as a will giving universal law. . . Hence the will is not merely subject to the law but subject to it in such a way that it must be viewed as also 
giving law to itself and just because of this as first subject to the law (of which it can regard itself as the author). ${ }^{35}$

Kant thus links the treatment man receives as a free and equal being, as an end-in-himself, with his capacity for self-legislation. ${ }^{36}$ One way to understand this complex relationship among the three formulations (though not the only way ${ }^{37}$ ) is to conceive of it as a dialectic. In the $1^{\text {st }}$ Formulation, universal law has dignity and looms over man as something external to him; this is the law of the Decalogue, handed down by God to man and ruling him from without. In the $2^{\text {nd }}$ Formulation, man himself has dignity owing to his freedom; he is set apart from the rest of nature by the independence of his will, and he assumes God's place of power in the natural order. This tension between the $1^{\text {st }}$ and $2^{\text {nd }}$ Formulations regarding the bearer of dignity (law or man) is resolved in the $3^{\text {rd }}$ Formulation by the conception of man as a self-legislator who spins out universal law from his own will and assumes God's place not only in power but also in responsibility - a responsibility born from the knowledge that the human will (like human reason) must be self-limiting.

The foregoing discussion of self-legislation leaves an important question unanswered, though: why is the presence or absence of an autonomous will, a will that acts from a self-chosen moral law, a reason for the kind of differential treatment of agents that we discussed earlier? The answer to this question (which can only be touched on here) lies at the heart of Kant's moral project. Kant believes that human beings qua rational agents are uniquely situated because they straddle two worlds: the world of sense and the world of understanding. ${ }^{38}$ As members of the world of sense, they are (like children and animals) under the reign of empirical laws of nature; as members of the world of understanding, on the other hand, they are free, subject only to rules that are the product of their own law-giving reason. ${ }^{39}$ Because they are the only beings known to us who can be free in this sense, they are the only beings who can participate in the moral law, as either authors or subjects. This capacity for freedom is the source of the rational agent's dignity, a dignity which distinguishes him from lesser beings and justifies not only his position in the status hierarchy but also the differential treatment that accompanies it.

This line of argumentation may be uncompelling to those (such as utilitarians) who have a different conception of moral philosophy's methods and aims.

${ }^{35}$ GMM, p. 39.

${ }^{36}$ “" The will of a rational being must always be regarded as at the same time lawgiving, since otherwise it could not be thought as an end in itself" (ibid., p. 42).

${ }^{37}$ See Rawls, "Themes in Kant's Moral Philosophy," pp. 504-6, for an alternative explanation, in which the different formulations represent varied points of view, or perspectives, on the same underlying principle.

${ }^{38}$ GMM, p. 56.

39 "For we now see that when we think of ourselves as free we transfer ourselves into the world of understanding as members of it and cognize autonomy of the will along with its consequence, morality ..." (ibid., p. 58). 
Nonetheless, the fact of man's self-legislating potential is arguably what drives our moral intuitions and actions (including our respect for the bodily integrity of rational agents) and explains our concern for status wrongs. One might think that such concern could be explained by species fellow-feeling alone, but such an explanation would fail to motivate our treatment of children, who are after all members of our own species but whom we subject to physical coercion for paternalistic reasons. Variation in the capacity for self-legislation appears to correlate remarkably well with variation in our treatment of agents. Moreover, there seems to be a direct connection between the notion of self-legislation and certain political forms, such as republican government. Kant himself alludes to this connection when he describes one of the attributes of the citizen as "lawful freedom, the attribute of obeying no other law than that to which he has given his consent." ${ }^{40}$ The ideal of self-government (personal and political) advocated by Kant continues to have a deep resonance in Western thought and may help to explain our simultaneous commitment to bodily integrity and republicanism, which is a kind of integrity of the body politic.

\section{CONCLUSION}

In the preceding pages, I presented two distinct but interrelated Kantian defenses of self-ownership. I began the paper by showing that Kant's objections to selfownership were not fatal, because the rights of self-ownership do not imply a liberty "to dispose of oneself as one pleases," that is, they are not inconsistent with the duty we have to respect humanity in our own persons, as required by the $2^{\text {nd }}$ Formulation of the Categorical Imperative. I then verified that maxims of exploitation and paternalism could not be universalized. More specifically, I proved that their universalization involves a contradiction in conception, because universal physical coercion (for selfish or paternalistic reasons) destroys the very preconditions of effective agency and autonomous willing. Finally, I argued that physical coercion against rational agents involves a profound status wrongnamely, the treatment of rational agents as children or animals. I then went on to show that this system of differential status, and the differential treatment that is associated with it, could be morally justified by looking as Kant did to man's nature as a self-legislating being.

In the conclusion to The Doctrine of Right, Kant argues for a "perpetual peace" that guarantees security of possession to both nations and their citizens. ${ }^{41}$ For nations, security of possession means territorial integrity and freedom from invasion, which can be attained through international laws, treaties, and federations. For individuals, security of possession means freedom from assault on one's person (bodily integrity) and on one's external property, which can be 
attained through a liberal political order and its associated protections (such as the enforcement of property rights and contract and the constitutional limitation of state power). Such security will clear the way for commerce (and its precondition, "cosmopolitan right"), which Kant advocates as an alternative to war and, by extension, to physical coercion domestically. ${ }^{42}$

Thus, without too much conceptual stretching, Kant's vision of a new and peaceful international order can be seen as self-ownership writ large or in macrocosm. In other words, his image of a federation of autonomous trading nations can be viewed as the global analogue for a nation of autonomous trading citizens. ${ }^{43}$ Kant clearly hoped that over time commerce would supersede war, voluntary cooperation would supplant coercion, and respect for boundaries would succeed the violations of bodily and territorial integrity that have characterized much of human history, and these hopes find their echoes in the self-ownership literature's consuming preoccupation with boundaries and their security.

${ }^{42}$ Ibid., p. 121. Cf. Benjamin Constant, "The liberty of the ancients compared with that of the moderns," The Political Writings of Benjamin Constant, trans. Biancamaria Fontana (Cambridge: Cambridge University Press, 1988), pp. 307-28.

${ }^{43}$ The preliminary Fifth Article of Kant's "perpetual peace" between states ("No state shall forcibly interfere in the constitution and government of another state") suggests that Kant himself was engaged in such analogizing (Kant, Political Writings, p. 96). He appears to regard such interference as a form of paternalism exactly like that exercised by sovereigns over their own citizens when they interfere with their freedom in order to promote their happiness. 